\title{
Exploration and Practice of Single Chip Microcomputer Curriculum Reform Based on Project-based Teaching
}

\author{
Kaibo $\mathrm{Si}^{1}{ }^{1,}{ }^{*}$ and Lilin Zhan ${ }^{2, b}$ \\ ${ }^{1}$ Xijing University, 1 Xijing Road, Changan District, Xi'an, Shaanxi \\ a155331277@qq.com, b zhanlilin1998@qq.com
}

\begin{abstract}
Keywords: Single-chip computer course; Professional technology; Curriculum reform; Project-based teaching
\end{abstract}

\begin{abstract}
The SCM course is a professional technical course for the electronics major. Its technical and applied nature is very strong. The project reform is adopted in the form of project-based teaching, which is conducive to students mastering course knowledge and development skills. The thesis is from project concept and course. The project design, assessment methods and significance of projectization are explored and practiced, and through implementation, good teaching results are achieved.
\end{abstract}

\section{Project Concept}

The category of "projectization" refers to learning theories based on cognitiveism and constructivism, including case-based teaching, project-based teaching, task-driven teaching, problem-based teaching (PBL), and other teaching methods. Personalized learning, cooperative learning, project-based learning, mobile learning, gamification learning, scholastic learning, and other diverse learning methods, and the comprehensive use of teaching methods that can achieve good results ${ }^{[1]}$.

\section{Course Project design and Implementation Process}

The SCM course is a very practical course. Therefore, the project-based teaching method is the main course in the teaching process ${ }^{[2]}$, and more practical hands-on links are arranged. Including typical project experiments, stage works, project cases, program design, on-machine test and physical production. The stage works are a summary of the staged learning results in the course teaching, which can comprehensively reflect the students' learning at this stage, including the use of instruments and equipment, the design of the circuit schematic, the design of the program source code, the simulation debugging, the work summary and Grades such as grades.

This course is based on the premise of learning the project ability of single-chip microcomputer to solve practical problems. Through the 5 items of LED water light, simple timer, stepper motor control, single chip and PC communication, temperature alarm, etc., the basic knowledge and basic principle of the single chip microcomputer will be adopted. Combined with the application method, the students can understand the law of single-chip control during the operation process, master the method of single-chip application, and experience the powerful control function of the single-chip microcomputer in the course of step-by-step project practice.

The curriculum project design should reasonably cover the learning content required by the syllabus, including the key points and difficulties that should be learned. Each project can follow the gradual difficulty of designing different tasks, and each task corresponds to the knowledge link of the teaching materials. The project design plan is illustrated by taking unit project 1 as an example.

Unit project one: LED water light

Project content: Learn the C51 programming process, familiar with the use of Keil logic analyzer, Proteus microcontroller simulation and the use of virtual instrumentation.

Task 1. LED single lamp lighting control

(1) Task Description Use Keil software to write programs to achieve lighting control of a single 
LED light.

(2) Task analysis Create a new MCU project, write a Keil program, and run the program.

(3) Knowledge link The principle of conduction and light emission of LED; the method of output level of single chip; the usage of pin key sbit; program design flow.

(4) Task implementation New MCU project, write Keil program, compile and debug, program run and debug.

Task 2. Use of Keil Logic Analyzer

(1) Task Description The use of the Keil Logic Analyzer.

(2) Task Analysis The logic analyzer looks at the I/O port output level waveform; the waveform is high and low time analysis.

(3) Knowledge link Delay control flicker frequency method; variable type effect on delay; MCU simulation process.

(4) Task implementation Complete the control function program to control the LED light for 0.5s and $0.5 \mathrm{~s}$ off.

Task 3. Proteus LED dual light flashing control

(1) Task Description The Proteus single-chip virtual simulation software is used to realize the LED double-light flicker control effect.

(2) Task analysis Set up LED dual-light control circuit and write control program.

(3) Knowledge link LED dual lamp circuit design method; the effect of current limiting resistor on brightness; and the method of controlling multiple lamps at the same time.

(4) Task implementation Complete the control of two different LEDs to have the function of alternating flashing or simultaneous flashing.

Task 4. Proteus LED Flood Light Control

(1) Task description The Proteus microcontroller virtual simulation software is used to realize the LED water light control effect.

(2) Task analysis Set up LED dual-light control circuit and write control program.

(3) Knowledge link LED flow lamp circuit design method; bit assignment method; byte assignment method; library function method.

(4) Task Implementation Complete the flow light control effect from left to right or from the middle to the sides of the 8 LED lights.

The flow chart of the implementation of the project curriculum is shown in Figure 1.

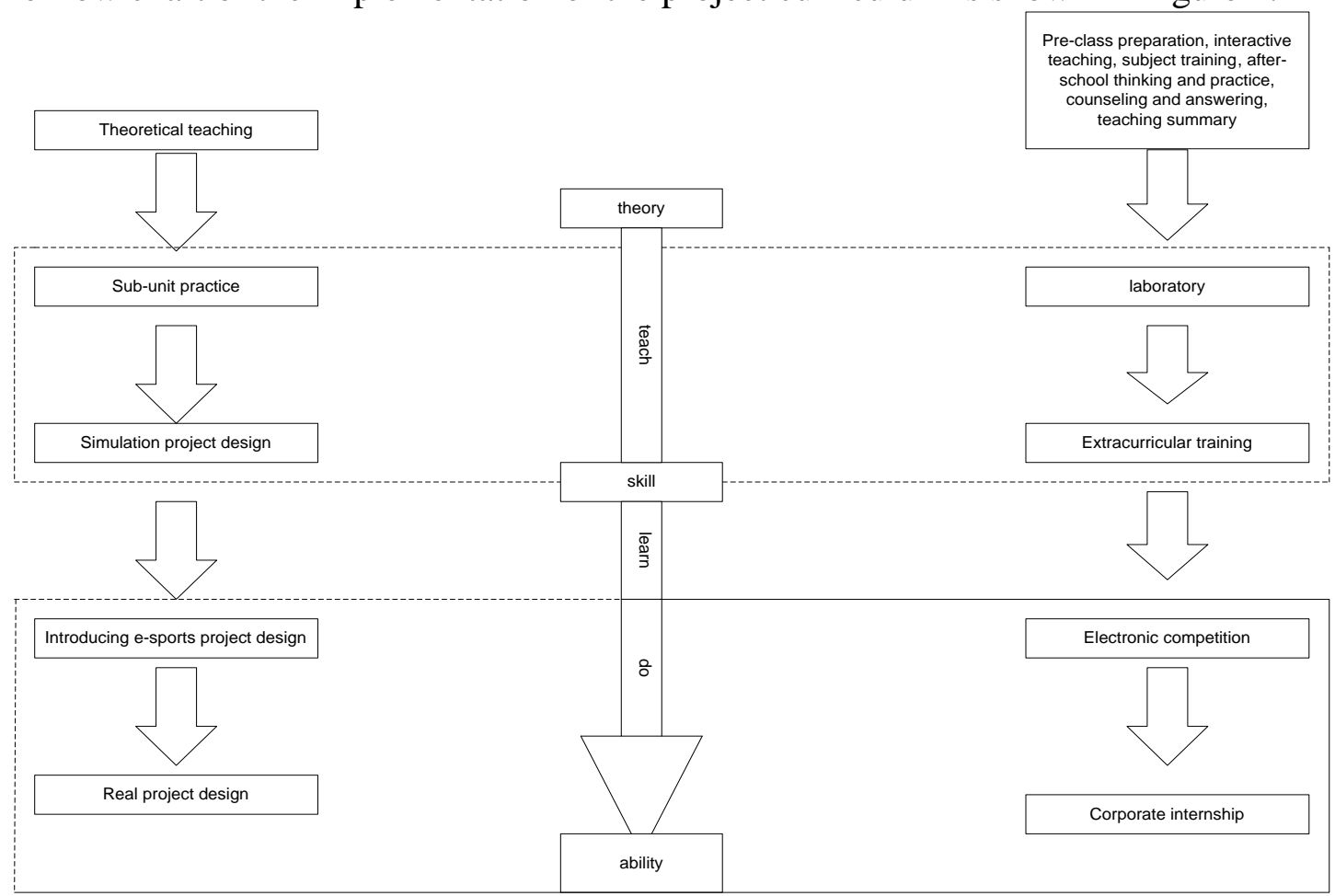

Figure 1. Project-based teaching implementation process 
The project-oriented teaching implementation process organizes the teaching content around the training of students' project ability and employability, and integrates the practical ideas of the development of MCU and the process into specific tasks [3-4]. Through the sub-project unit exercises, the simulation of the comprehensive project design, The introduction of e-sports projects to real projects, so that students learn from theory to skills to ability, the teaching effect to achieve "teaching, learning, doing" integration.

\section{Assessment Methods}

In all aspects of the teaching process, students are assessed in all aspects from the attendance, daily performance, homework, testing, project completion and quality of completion [5-6]. The assessment plan is shown in Table 2.

Table 2 Assessment plan

\begin{tabular}{|c|c|c|c|c|c|}
\hline Category & $\begin{array}{l}\text { Exam } \\
\text { topic }\end{array}$ & $\begin{array}{c}\text { The main content } \\
\text { of the assessment } \\
\text { and its knowledge } \\
\text { points }\end{array}$ & Assessment method & Exam time & $\begin{array}{l}\text { The } \\
\text { proporti- } \\
\text { on }\end{array}$ \\
\hline \multirow{2}{*}{$\begin{array}{l}\text { Formative } \\
\text { assessment }\end{array}$} & $\begin{array}{c}\text { Usual } \\
\text { assessment }\end{array}$ & $\begin{array}{c}\text { Daily } \\
\text { performance }\end{array}$ & $\begin{array}{c}\text { Attendance, } \\
\text { homework, classroom } \\
\text { performance }\end{array}$ & $\begin{array}{l}\text { End of } \\
\text { course }\end{array}$ & $20 \%$ \\
\hline & $\begin{array}{c}\text { Unit } \\
\text { assessment }\end{array}$ & $\begin{array}{l}\text { Project } \\
\text { completion and } \\
\text { unit knowledge }\end{array}$ & $\begin{array}{l}\text { Project report and } \\
\text { program quality } \\
\text { evaluation }\end{array}$ & $\begin{array}{l}\text { End of } \\
\text { each } \\
\text { project } \\
\text { week }\end{array}$ & $40 \%$ \\
\hline $\begin{array}{c}\text { Final } \\
\text { assessment }\end{array}$ & $\begin{array}{c}\text { Final } \\
\text { assessment }\end{array}$ & $\begin{array}{l}\text { Mastery of all } \\
\text { knowledge test } \\
\text { sites }\end{array}$ & Great job & $\begin{array}{c}\text { Two } \\
\text { weeks } \\
\text { after the } \\
\text { end of the } \\
\text { course }\end{array}$ & $40 \%$ \\
\hline
\end{tabular}

\section{The Significance of Curriculum Reform}

The curriculum project reform is of great significance for the transformation of new undergraduate colleges into applied technology universities, mainly reflected in[7-10]:

(1) Cultivate students' "project ability" through project-based teaching, start from time management and responsibility, and make up for the incompatibility between graduation and employment; only professional knowledge, lack of social/personal ability and method/learning ability.

(2) Project-based teaching can take the activity teaching mode, use the task-driven method, and complete the task to drive the theoretical class with practical hands-on operation. Through this repeated practice similar to the professional environment, students can gain professional ability and enhance their employability.

(3) The project and task design adopts the gradient advanced mode, adopting the teaching method of "theory-practice-self-study theory-innovation practice", corresponding to different experimental sites according to the project implementation process, rolling forward, stimulating students' potential and cultivating students' project ability.

(4) The project-based teaching evaluation system is more reasonable. It abandons the past single test evaluation and tries to construct a diversified evaluation system including usual performance, project results, program quality, and report writing. It examines students in many aspects and improves the overall quality of students. 


\section{Conclusion}

The project-oriented teaching reform is guided by the employer's employability, focusing on practical operations, taking into account the syllabus knowledge points, integrating knowledge points into design projects, breaking chapter restrictions, working tasks as the framework, action system as the framework, and typical case scenarios. In order to guide the curriculum reform design, through the author's practice in the classroom, students have a deeper understanding of the MCU development process than traditional teaching. They have certain project capabilities and have the initial ability to develop independently. They have good reference significance for other curriculum reforms.

\section{References}

[1] Interpretation of the policy of "one teacher and one excellent class" and the construction of project-oriented curriculum. Xijing College.2015.12

[2] Weibing Chen, Hui LI, Hongqi Cao. Research on Teaching Reform of Single-Chip Course Based on the Combination of Engineering and Learning[J]. Journal of Nantong Vocational University, 2013, (01): 49-51.

[3] Huizhong Ran. Implementation of Project-based Teaching Method in SCM Course[J]. Journal of Chengdu Textile College, 2012, (04): 57-58.

[4] Zilong Dai. The Application of Modular Based Single-Chip Project Development System in the Training of Middle School Students' Action Ability_-Taking the Simple Calculator System Project Teaching Method as an Example[J]. Occupation, 2016, (24): 142-143.

[5] Yingjuan Qu, Liming Fu. Japanese Teaching Research for the Purpose of Training Applied Japanese Talents[J]. Journal of Jixi University, 2014, (09): 83-84+87.

[6] Lizhi Liu. Discussion on the Improvement of Teaching Methods of Database System Introduction Course[J]. Fujian Computer, 2015, (07): 129-130+145.

[7] Libing. Project teaching reform and practice of Li Bing MCU Course [J]. laboratory science, 2014,17 (01): 101-103.

[8] Tang Luxin, Fan Hangjun, Wu Liming, Li Yang. Exploration of advanced experimental teaching inspired by SCM technology course [J].Laboratory Research and Exploration, 2015, 34 (09): 203-207.

[9] Wang Jin, Yuan Zhanjun.Application of Virtual Simulation Technology in the Teaching of Single Chip Microcomputer Course[J].Electronic Design Engineering,2016,24(01): 45-47+51.

[10]Zhao Yuejing, Chen Jirong, Zhang Yongdi. Innovative Practical Teaching Reform of Principles and Applications of Single Chip Microcomputer [J]. Experimental Technology and Management, 2013, 30 (01): 176-179. 